\title{
Estimation of soil loss rate using the USLE model for Agewmariayam Watershed, northern Ethiopia
}

\author{
Gebrehana Girmay ${ }^{1 *}$, Awdenegest Moges ${ }^{2}$ and Alemayehu Muluneh ${ }^{2}$
}

\begin{abstract}
Background: Soil erosion and nutrient depletion threaten food security and the sustainability of agricultural production in sub-Saharan Africa. Estimating soil loss and identifying hotspot areas support combating soil degradation. The aim of this paper is to estimate the soil loss rate and identify hotspot areas using USLE model in the Agewmariam watershed, northern Ethiopia.

Methods: Rainfall erosivity factor was determined from annual rainfall, soil erodibility factor from soil data, slope length and gradient factor were generated from DEM, cover factor and conservation practice factor obtained from land use cover map. Finally, the parameters were integrated with ArcGIS tools to estimate soil loss rates of the study watershed.

Results: Mean annual soil loss rates were estimated to be between 0 and $897 \mathrm{t} \mathrm{ha}^{-1}$ year ${ }^{-1}$ on flatter and steeper slopes, respectively. The total annual soil loss was 51,403.13 tons from the watershed and the annual soil loss rate of the study area was $25 \mathrm{t} \mathrm{ha}^{-1}$ year ${ }^{-1}$. More than $33 \%$ of the study areas were above tolerable soil loss rate $\left(11 \mathrm{t} \mathrm{ha}^{-1}\right.$ year $\left.{ }^{-1}\right)$. The spatial risk categorization rate was $67.2 \%$ severe $\left(>51 \mathrm{t} \mathrm{ha}^{-1}\right.$ year $\left.^{-1}\right), 5.4 \%$ very high $\left(31-50 \mathrm{t} \mathrm{ha}^{-1}\right.$ year $\left.^{-1}\right)$, 5.8\% high (19-30 t ha ${ }^{-1}$ year $\left.^{-1}\right), 3.2 \%$ moderate $\left(12-18\right.$ t ha $^{-1}$ year $\left.^{-1}\right)$ and $18.3 \%$ slight $\left(0-11\right.$ t ha $^{-1}$ year $\left.^{-1}\right)$.

Conclusion: The results showed that the severity of erosion occurred on the steep slope cultivation, absence of conservation measures, and sparse nature of the vegetation cover. This area required immediate action of soil and water conservation which accounts for about $33.5 \%$ of the total watershed.
\end{abstract}

Keywords: Ethiopia, Soil loss, Soil loss tolerance, USLE

\section{Background}

Soil erosion is an extensive land degradation problem in many parts of the world. The loss of soil from the land surface by erosion is widespread globally and adversely affected by the productivity of all-natural ecosystems as well as agricultural, rangeland, and forest ecosystems [45]. The worldwide annual rate of soil erosion from agricultural land ranges from 22 to $100 \mathrm{tha}^{-1}$ and declines in

*Correspondence: geberhanagirmay@gmail.com

1 Soil and Water Management, Sekota Dryland Agricultural Research Center, Sekota, Ethiopia

Full list of author information is available at the end of the article productivity as much as $15-30 \%$ annually [40]. According to Morgan [40], soil erosion costs the US economy between US $\$ 30$ billion and US $\$ 44$ billion annually related to on-site (cost of production and production loss) and off-site (pollution and sedimentation of downstream water resources) effects of soil erosion.

Land degradation, in the form of soil erosion and nutrient depletion, threatens food security and the sustainability of agricultural production in sub-Saharan Africa [34]. Soil erosion is a common phenomenon in the East African highlands, where it causes widespread soil degradation [21, 52]. Especially, in East Africa, where Ethiopia shows the highest erosion rates [25,

c) The Author(s) 2020. This article is licensed under a Creative Commons Attribution 4.0 International License, which permits use, sharing, adaptation, distribution and reproduction in any medium or format, as long as you give appropriate credit to the original author(s) and the source, provide a link to the Creative Commons licence, and indicate if changes were made. The images or other third party material in this article are included in the article's Creative Commons licence, unless indicated otherwise in a credit line to the material. If material is not included in the article's Creative Commons licence and your intended use is not permitted by statutory regulation or exceeds the permitted use, you will need to obtain permission directly from the copyright holder. To view a copy of this licence, visit http://creativeco mmons.org/licenses/by/4.0/. The Creative Commons Public Domain Dedication waiver (http://creativecommons.org/publicdomain/ zero/1.0/) applies to the data made available in this article, unless otherwise stated in a credit line to the data. 
35]. The annual soil loss rate by water ranges from 16 to $300 \mathrm{t} \mathrm{ha}^{-1}$ year $^{-1}$ in Ethiopia, mainly depending on the degree of slope gradient, intensity, and type of land cover and nature of rainfall intensities [30, 51]. Land degradation in Ethiopia is especially severe in the highlands where the annual soil loss from farmland is estimated to 100 to $300 \mathrm{t} \mathrm{ha}^{-1}$ year $^{-1}[8,54]$. It has been estimated that out of 60 million hectares of agriculturally productive land, about 27 million hectares are significantly eroded and 2 million hectares of land have already been irreversibly lost from productive uses [8, 54]. Loss of arable land due to soil erosion is a widespread phenomenon in the highlands which accounts for about $45 \%$ of Ethiopia's total land [54].

Rapid population growth, cultivation on steep slopes, clearing of vegetation, and overgrazing are the main factors that accelerate soil erosion in Ethiopia, more specifically in the Amhara regional state [13]. According to Desta [13] the principal problem in the Amhara region, with land estimated to be eroding at very rapid rates of $16-50 \mathrm{t} \mathrm{ha}^{-1}$ year $^{-1}$. Soil erosion by water is the dominant form of erosion of the study area that is severely affected found in Wag-Himra and north Wollo [13]. The understanding of soil erosion processes plays a critical role in planning, designing, and implementing appropriate soil and water conservation policy strategies [49]. In the study area, the land management methods being practiced do not consider variations in degrees of soil erosion, climate, topography, soils, and land use/land cover factors. Direct Field measurements of soil erosion at permanent research or experimental stations using runoff plots with the known area, slope gradient slope length, and soil type could give reliable runoff and soil loss [32] for experimental purposes, however, it is costly, labor-intensive, and timeconsuming [1]. Alternatively, it is possible to estimate the average soil loss using empirical models that can be used as predictive tools for inventories, conservation and project planning, decision-making, and policy development [41]. Therefore, the objective of the study was to assess soil loss rate and identify hot spot areas using USLE of Agewmariayam Watershed, in Northern Ethiopia.

\section{Materials and methods}

\section{Description of the study area}

The study was conducted at Agewmariam watershed situated in SaydakebeleSekotaworeda of Wag-Himra Administration zone in Amhara Regional State about $720 \mathrm{~km}$ north of Addis Ababa. The study area covers 183.3 ha, with elevation ranging from 2075 to $2393 \mathrm{~m}$ above sea level (Fig. 1).

\section{Climate}

The study area is characterized by a uni-modal rainfall pattern, the main rain extends from late June to early September. The mean annual rainfall of the area varied from 689.3 to $1087.9 \mathrm{~mm}$ and the mean minimum and maximum annual temperatures are $12.8{ }^{\circ} \mathrm{C}$ and $28{ }^{\circ} \mathrm{C}$, respectively (Fig. 2). The area belongs to a dry semi-arid lowland [12].

\section{Land uses and crop production in the study area}

The study watershed has four major land-use types: agricultural land (71.4\%), bushland (19\%), area closure (8.2\%), and the rest are village or settlement [59]. Most of the lower and upper parts of the watershed are cultivated land, bush and grazing land are found in the middle hillside parts of the watershed.

The landholding size in the watershed is characterized as small and fragmented less than 0.75 ha per household [9]. Cultivation as the livelihood in the watershed, the major crops grown are sorghum (Sorghum bicolor L.), wheat (Triticum aestivum L.), barley (Hordeum vulgar L), teff (Eragrostis teff (Zuss) Trotter), chickpea (Cicer arietinum $L$.), and faba bean (Vicia faba L.).

\section{Data sources}

The USLE model variables are estimated from various sources. Rainfall erosivity factor ( $R$-value) was derived from annual rainfall data from the Koziba meteorology station. Soil erodibility factor ( $K$ value) determined from field-estimated organic matter, texture, structure, and permeability of the soil of the study area. Slope length and slope gradient factor (LS value) were obtained from the analysis of SRTMDEM with $30 \mathrm{~m}$ resolution. The crop factor $(C)$ and conservation practice factor $(P)$ are estimated by analyzing Landsat image and DEM (Fig. 3).

\section{Details on derivation of USLE parameters Erosivity factors ( $R$ )}

The erosivity factor $R$ was calculated using the equation given in Hurini [33] adapted for the Ethiopian condition which has been derived from spatial regression analysis [31] (Eq. 1). Other studies have also reported successfully using the equation $[3,4,7,22,26,36,48,58]$.

The $R$-factor is given by a regression equation as:

$$
R=-8.12+0.562 P
$$

where $R$ is the erosivity factor and $P$ is the mean annual rainfall $\left(\mathrm{mm}_{\mathrm{year}}{ }^{-1}\right)$.

\section{Soil erodibility factor $(K)$}

Soil samples (155) were collected from the study watershed by a grid of $100 \times 100 \mathrm{~m}$ and sample for analysis was collected from the center of each grid. The 155 soil 


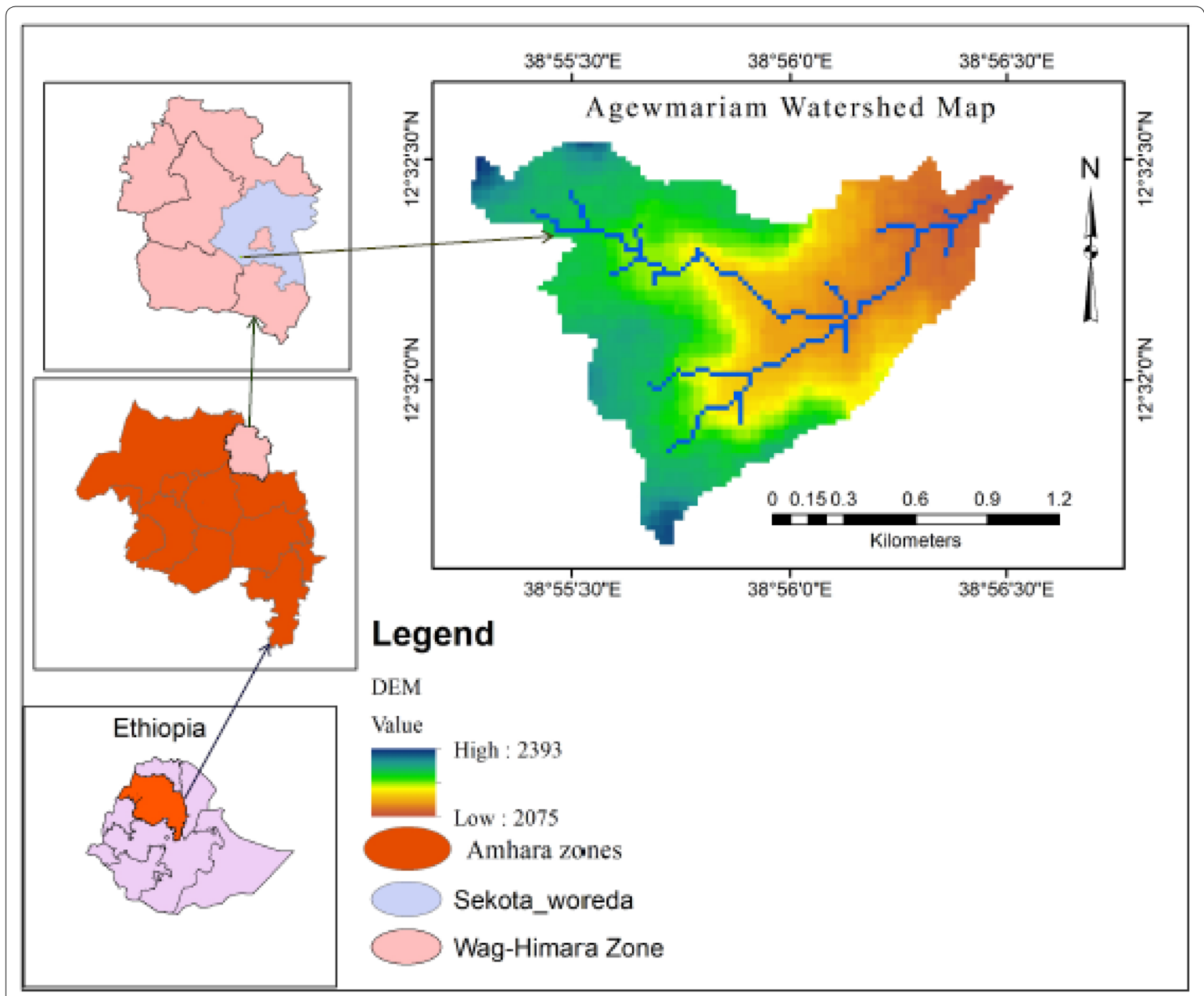

Fig. 1 Location map of the study area $[15,16]$



Fig. 2 Thirty years' average mean monthly rainfall and mean monthly minimum and maximum temperatures of Kosibaa station near the study area (data from NMSA, 2018 unpublished document) samples were collected to determine the physical and chemical properties of the soil. The properties of analyzed are organic matter content, texture, structural, and permeability.

Analysis of the soil samples was performed based on the standard laboratory procedures. Particle size distribution was analyzed using the hydrometer method [23], whereas organic carbon was determined by the wet combustion method of Walkley and Black as outlined by Nelson and Sommers [42].

Soil structure was identified under field condition with the help of a soil structure assessment kit to determine soil structural class code. Soil structural class code was determined based on the observed shape and size of soil structure as adopted from the USLE nomograph [57]; whereas, the permeability class code was obtained 


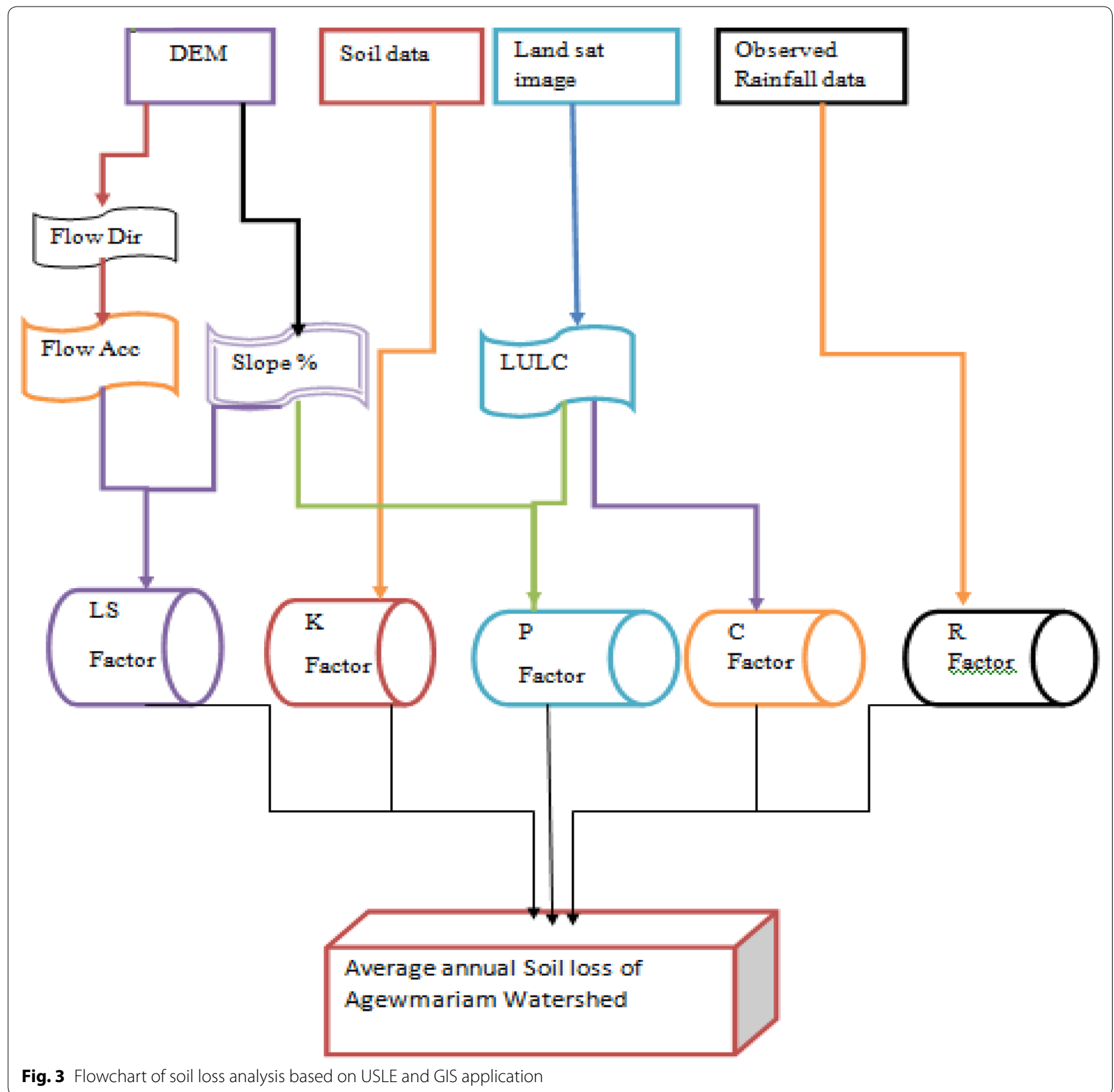

from soil textural classes [10], which are encoded from the textural triangle based on the observed soil texture.

$K$ factor was calculated from estimated soil properties, namely texture, organic matter, and structural and permeability $[20,44]$. In this study, the $\mathrm{K}$ factor was calculated (Eq. 2) and mapped [28, 48, 58].

$$
\begin{aligned}
K(\text { factor })= & 2.77 * 10^{-7}(12-\mathrm{OM}) M^{1.14}+4.28 * \\
& 10^{-3}(s-2)+3.29 * 10^{-3}(p-3),
\end{aligned}
$$

where

$$
M=[(100-C)(L+\mathrm{Armf})],
$$

$C$ is \% of clay $(<0.002 \mathrm{~mm}), L$ is \% of silt $(0.002-0.05 \mathrm{~mm})$ and Armf is \% of very fine sand $(0.05-0.1 \mathrm{~mm}), \mathrm{OM}$ is the organic matter content (\%), $p$ is a code indicating the class of permeability and $s$ is a code for structure size.

Soil sample points of erodibility factors were converted to surface data by interpolation techniques using ordinary kriging in the ArcGIS environment and the Gaussian model. 


\section{Slope length and gradient factor (LS)}

Slope length and gradient factors were estimated by ArcGIS 10.3.1. In this study, the SRTMDEM with a resolution (grid cell) of $30 \mathrm{~m}$ by $30 \mathrm{~m}$ which is available by USGS Earth explorer. The flow accumulation, slope steepness, and slope gradient were generated from DEM in the Arc GIS environment. The LS map was generated using Eq. [5] developed by Wischmeier and Smith [57]. Similar approach also used by other researchers $[22,24$, 48].

$$
\mathrm{LS}=(X / 22.1) m\left(0.065+0.045 S+0.0065 S^{2}\right)
$$

$$
\mathrm{X}=(\text { Flow accumulation * Cell value })
$$

where LS is slope length-steepness factor, $X=$ slope length $(\mathrm{m}), m=\mathrm{a}$ variable slope-length exponent, and $S=$ slope gradient (\%). Flow accumulation is a grid theme of flow accumulation expressed as a number of grid cells while cell size is the length of a cell side in meter $(\mathrm{m})$. Flow accumulation was derived from the DEM, after conducting fill-and-flow direction processes in the Arc GIS environment in line with the Arc Hydro tool and was calculated by the raster calculator of the map algebra expression, whereas the value of $\mathrm{S}$ was directly derived from 30-m resolution DEM.

\section{Crop management factor (C)}

Crop management factor for different land use was derived from satellite images based on land use and land cover maps and its attribute data analysis. The cover and management factor is the ratio of soil loss from land with specific vegetation to the corresponding soil loss from fallow with the same rainfall [57]. The LANDSAT satellite image was used from USGS on January 20, 2018, to drive Land use and cover map. Supervised digital image classification techniques were employed using ArcGIS 10.3.1 software.

Land use classification was conducted by the maximum likelihood classification method creating 150 training signatures. 123 reference points were generated from Google Earth for validation.
A systematic sampling technique was used to evaluate the accuracy of the LULC classification of the study area. To measure agreement between image classification results and ground truth overall accuracy, user accuracy, producer accuracy, and Kappa coefficient were used [53, 56]. Finally, three land use and land covers were identified as cultivated, forest, and shrubland (Table 1).

The corresponding $(C)$ values were assigned to each land use and land cover classes using reclassify tools in ArcGIS 10.3.1 environment. Finally $(C)$ factors raster layer of the study area was created by assigning adapted (C) value for each land use and land cover classes.

\section{Erosion control practice factor $(P)$}

The erosion control practice factor is the ratio between the soil losses expected for a certain soil conservation practice to that of up and downslope plowing [57]. Thus, the $P$-factor for USLE can be mapped through by collecting data from field observations [3, 7, 22]. However, in the study area, there were no conservation measures, as data were lacking on permanent management factors and there were no management practices the $P$-factor suggested by Wischmeier and Smith [57]. This method has also been used in the highlands of Ethiopia by others [4, $24,37,48,54]$. This method categorizes land covers into agricultural land, shrubland, and forest land. $P$ value was assigned 0.1 and 1 regardless of their slope for shrub and forest. However, $P$-value for agricultural land was given corresponding to its slope, so sub-divided into six classes $0-5,5-10,10-20,20-30$, and $>50 \%[3,4]$.

\section{Soil loss analysis}

The average annual soil loss was calculated on a grid cell basis by multiplying the respective USLE factor values ( $R, K, L S, C$, and $P$ ) interactively using the "Spatial Analyst Tool Map Algebra Raster Calculator" in Arc GIS environment.

Where $A$ is the annual soil loss $\left(\mathrm{t} \mathrm{ha}^{-1}\right.$ year $\left.{ }^{-1}\right) ; R$ is the rainfall erosivity factor $\left(\mathrm{MJ} \mathrm{mm} \mathrm{h} \mathrm{hm}^{-1} \mathrm{ha}^{-1}\right.$ year $\left.^{-1}\right) ; K$ is soil erodibility factor $\left[\mathrm{Mg} \mathrm{ha}^{-1} \mathrm{MJ}^{-1} \mathrm{~mm}^{-1}\right]$; $\mathrm{LS}=$ slope length factor (dimensionless); $C$ is management factor (dimensionless); and $P$ is conservation practice factor (dimensionless).

Table 1 Description of three identified land use land cover types [43]

\begin{tabular}{ll}
\hline Land use/cover classes & Descriptions \\
\hline $\begin{array}{l}\text { Cultivated land } \\
\text { Shrubland }\end{array}$ & $\begin{array}{l}\text { Land that cultivated annual crops. This includes rainfed, and including rural homesteads } \\
\text { with scattered herbs and shrubs can be sometimes found }\end{array}$ \\
Forest & Areas covered with trees forming canopy cover greater than $30 \%$. This includes trees mixed with shrubs area closure
\end{tabular}




\section{Results and discussion}

\section{Rainfall erosivity $(R)$ factors}

The annual rainfall of the study area was $890.23 \mathrm{~mm}$. The result showed that the average $R$-factor value in the study area was $499.2 \mathrm{MJ} \mathrm{mm} \mathrm{ha}{ }^{-1} \mathrm{~h}^{-1}$ year $^{-1}$. The $R$-value is lower its indicates that low erosivity of rainfall to erode the soil [4] and low the rainfall intensity the study area [14].

\section{Soil erodibility $(K)$}

The soil analysis result is reported in Table 2.

Table 2 Statistical summary of soil parameters in the study watershed

\begin{tabular}{llllll}
\hline Soil parameter & Minimum & Maximum & Mean & STDEV & CV \\
\hline Sand & 49 & 92 & 71 & 9.8 & 0.14 \\
Silt + very fine sand & 3 & 30 & 18 & 5.7 & 0.5 \\
Clay & 4 & 31 & 12 & 5.6 & 0.32 \\
Organic matter & 0.03 & 5.5 & 1.3 & 1.2 & 0.9 \\
\hline
\end{tabular}

CV-coefficient of variation, STDEV-standard deviation.
Based in Table 2 result the spatial prediction map of soil erodibility factor is illustrated in Fig. 4. The result indicates the central and eastern parts of the watershed erodibility factors range from 0.079 to $0.129 \mathrm{Mg} \mathrm{h}$ $\mathrm{MJ}^{-1} \mathrm{~mm}^{-1}$ and the northern and southern parts of the watershed range from 0.13 to $0.173 \mathrm{Mg} \mathrm{h} \mathrm{MJ}^{-1} \mathrm{~mm}^{-1}$. The $K$-value of the study area ranged from 0.079 to 0.173 . The current result also agrees with similar findings reports in the $K$ values of tropical soils that range from 0.06 to 0.48 [17] and most Ethiopian soils have the $K$ values ranged from 0.05 to 0.6 [19]. Contrary to our result, values ranging from 0.018 to 0.033 from GumraMaksegnit Watershed in the northwestern Amhara [28] and values ranging from 0.0008 to 0.0073 in western Iran (Vaezi et al. [55]) were reported. These lower values may be recorded because of high organic matter and surface aggregates. In our study, the mean organic mater was $1.3 \%$ in a range from 0.86 to $2.59 \%$, which low organic mater [50]. The high $\mathrm{K}$ value indicates high erodible and vulnerable to soil erosion which could be attributed to low clay and organic matter contents as less aggregation of soil colloids [6].

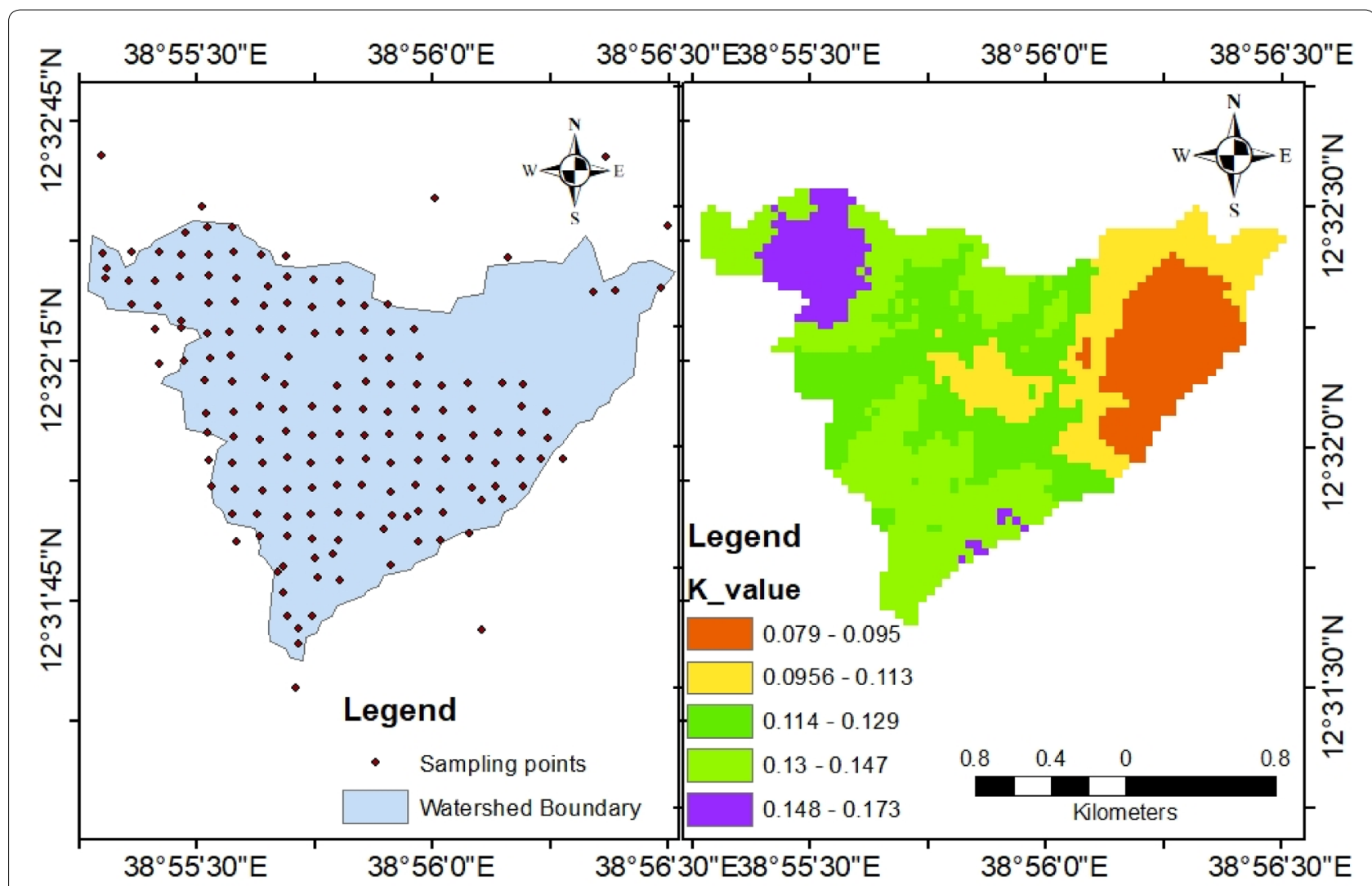

Fig. 4 Soil sample distribution and spatial prediction of soil erodibility factor 


\section{Topography factor (LS)}

The area coverage of LS factor values in class categories is given in Table 3 . The average LS factor was 16.33 with the standard division of 26.7. The LS factor value ranges from 0 to 311 (Fig. 7a). Topographic characteristics have a significant impact on the spatial distribution of erosion and deposition [39]. The current result of LS range values also agrees with the highland areas of Ethiopia as reported by $[4,37,48]$. The result shows that northern and southern part of the study area, hillsides and along the gullies had higher LS value (Fig. 8a) and it represents higher susceptibility to erosion may be due to the greater accumulation of runoff and high velocity $[2,3,22,48,57]$.

\section{Cover and management factor $(C)$}

The cover and management factor is the ratio of soil loss from the land with specific vegetation to the corresponding soil loss from fallow with the same rainfall [57]. According to the image classification result of the study area, three land use and land cover images were identified as cultivated land, forest, and shrubland (Fig. 5).

The area coverage for land uses was defined (Fig. 5 and Table 5) and shows that cultivated land was the largest proportion of the study area, followed by shrubland and forestland. The classified land use and land cover map from satellite images may have various types of errors. Therefore, accuracy assessment was done to check the compatibility of produced classification which exists in reality.

The accuracy result of the study shows (Table 4) that the agricultural land was the most accurately classified land use and land cover followed by shrub and forest land. The overall accuracy and Kappa coefficient results in the study area were 86.54 and 0.78 , respectively, which is beyond a threshold value of overall accuracy mentioned by Hardy et al. [29], while the acceptable level of overall accuracy is above $85 \%$. The kappa coefficient agrees with other similar studies $[53,56]$.

The average value of cover and management factors in the Agewmariyam watershed was 0.053 . The cultivated land had a maximum cover factor which indicated that

Table 3 Topography factor class, area coverage, and percentages in the study watershed

\begin{tabular}{lcc}
\hline LS class & Area in ha & Percent \\
\hline $0-10$ & 106.29 & 57.9 \\
$10-20$ & 26.28 & 14.3 \\
$20-50$ & 37.44 & 20.4 \\
$50-100$ & 10.44 & 5.7 \\
$100-311$ & 2.70 & 1.5 \\
\hline
\end{tabular}

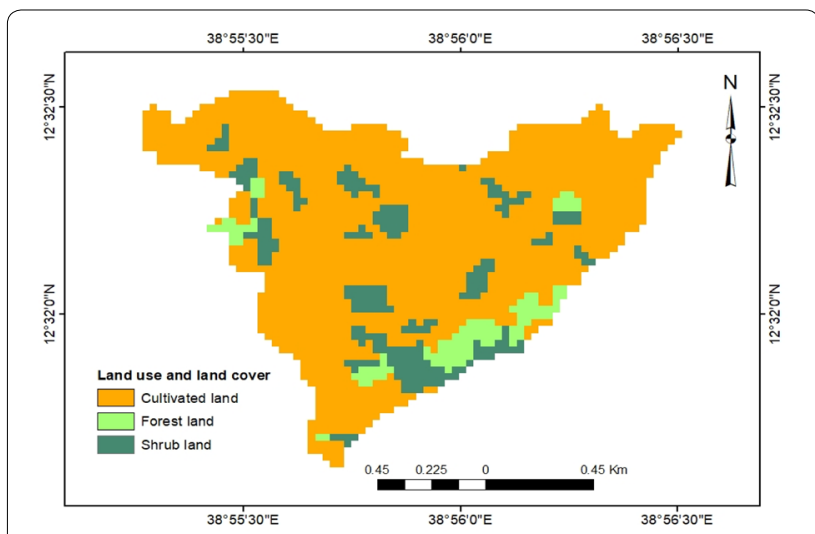

Fig. 5 Land use and land cover classification map of the study area

higher erosion. It covers the largest of the land use of the study area.

\section{Conservation practice factor $(P)$}

The conservation practice $(P)$ factor or also known as erosion control practice factor is the ratio of soil loss with a specific conservation practice like contouring, stripcropping, or terracing measures to the corresponding loss with up and downslope cultivation [57]. The land uses and the slope classes are as given in Fig. 6.

$P$-value was assigned 0.8 and 1 regardless of their slope for shrub and forest. The agricultural land sub-divided into six classes based on the slope percentage $(0-5,5-10$, $10-20,20-30$, and $>50 \%)$ and the assigned values are shown in Table 5 and Fig. $7 \mathrm{~d}$. High $P$ values are determined from agricultural land practiced on slope classes greater than $30 \%$ after forest land and shrubland.

Table 4 Error matrix for accuracy assessment of land use and land cover of the study area

Cultivated Forest Shrub Row total Users

accuracy

(\%)

\begin{tabular}{llllll}
\hline Cultivated land & 54 & 1 & 5 & 60 & 90 \\
Forest & 1 & 10 & 1 & 12 & 83.3 \\
Shrubland & 6 & 1 & 44 & 51 & 86.3 \\
$\begin{array}{l}\text { Column total } \\
\text { Producers accu- }\end{array}$ & 61 & 12 & 50 & 123 & \\
$\quad 93.69 \%$ & $83.33 \%$ & $90.16 \%$ & & \\
$\begin{array}{l}\text { racy } \\
\text { Overall accuracy }\end{array}$ & & & & $86.54 \%$ & \\
Kappa & & & & 0.78 & \\
\hline
\end{tabular}




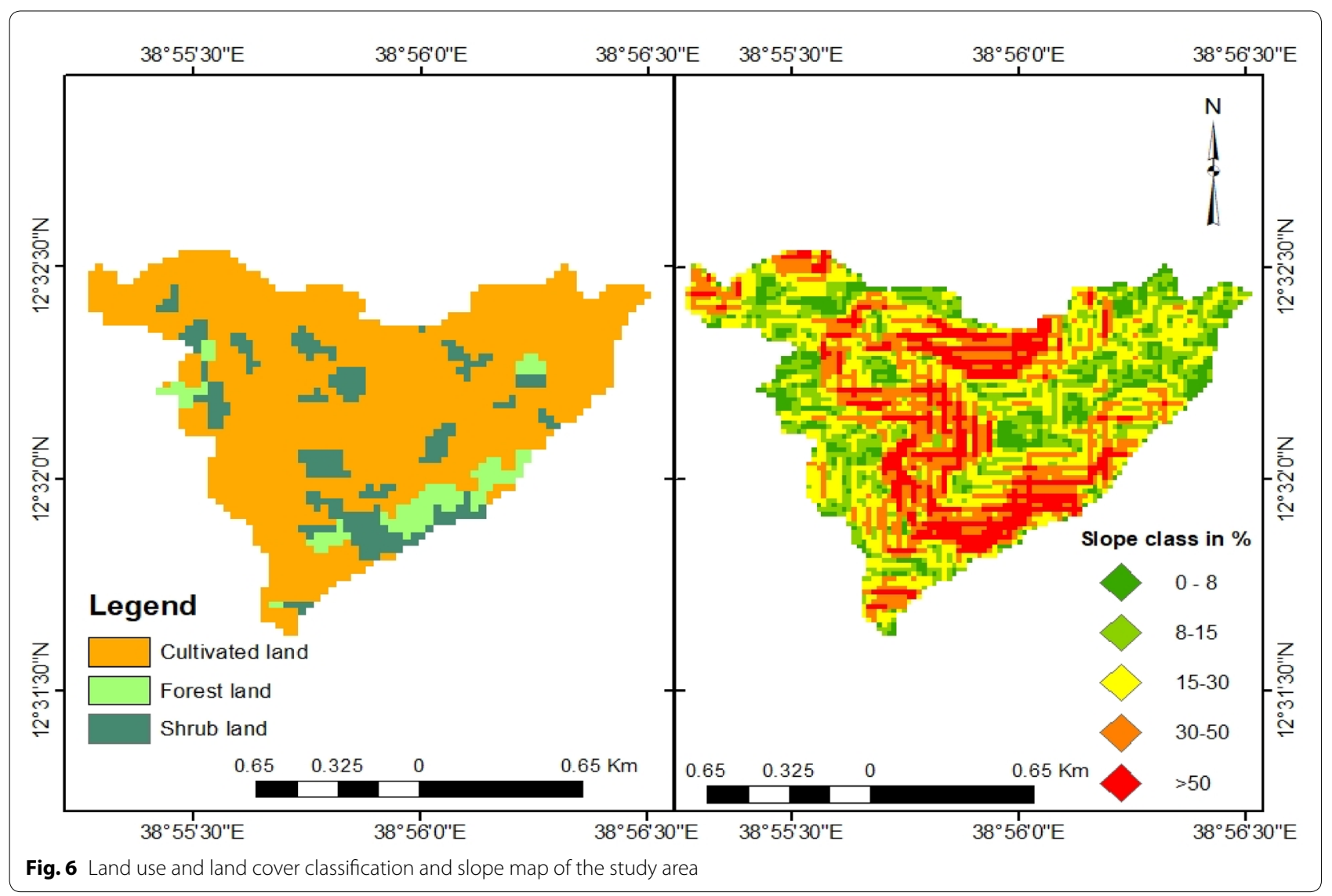

Table 5 Land use, area coverage, and cover management factor for the study area

\begin{tabular}{lllll}
\hline Land-use type & Area in ha & Area \% & C factor & References \\
\hline Cultivated land & 149.60 & 81.65 & 0.15 & $\begin{array}{c}\text { Hurni [33], Bewket and } \\
\text { Teferi [7], Amsalu } \\
\text { and Mengaw [3] }\end{array}$ \\
Forest land & 10.55 & 5.80 & 0.01 & $\begin{array}{c}\text { Hurni [33], Morgan [40] } \\
\text { Shrub land }\end{array}$ \\
& 23.0 & 12.55 & 0.014 & $\begin{array}{c}\text { Wischmeier and Smith } \\
{[57] \text { and Shiferaw }} \\
{[48]}\end{array}$ \\
& 183.15 & 100 & & \\
Total & & & &
\end{tabular}

\section{Soil erosion risk assessment}

Annual soil loss was estimated by integrating rainfall erosivity, soil erodibility, topography, cover management, and supporting factors in spatial analyst tool Arc GIS software. The final USLE map displays the average annual soil loss potential (A) of the Agewmariam watershed shown in Fig. 8.

The average annual soil loss rate was $25 \mathrm{t} \mathrm{ha}^{-1}$ year $^{-1}$ ranging from $0 t \mathrm{ha}^{-1}$ year $^{-1}$ in the plain area to 897 $t$ ha $^{-1}$ year $^{-1}$ in the hilly terrains of the watershed. The maximum soil loss occurs on the hilly terrains and the mainstream this perhaps is because of high LS factor value (50 to 311 ) slope gradient greater than $30 \%$ [11]. The total annual soil loss was 51,403 tons. The erosion rate risk classification was categorized into five classes as shown in Table 8 and Fig. 8 . The result showed that about $67 \%$ of the area is characterized by slight erosion rate (0-11 $\mathrm{t} \mathrm{ha}^{-1}$ year $\left.^{-1}\right)$ and such areas can be considered low-risk areas. The remaining areas are categorized as moderate (11-18 $\mathrm{t} \mathrm{ha}^{-1} \mathrm{year}^{-1}$ ) erosion risk area (5.43\%); high-risk (18-30 t ha ${ }^{-1}$ year $^{-1}$ ) erosion area (5.78\%); very high-risk (30-50 $\mathrm{t} \mathrm{ha}^{-1}$ year $^{-1}$ ) erosion area (3.25\%) and severely affected (50-897 $\mathrm{t} \mathrm{ha}^{-1}$ year ${ }^{-1}$ ) erosion area (18.36\%) (Table 8).

The average annual soil loss rate estimated for entire watershed was $25 \mathrm{t} \mathrm{ha}^{-1}$ year $^{-1}$ which is comparable to other reports by Hurni [33] for the highland of Ethiopia (20 t ha ${ }^{-1}$ year $\left.^{-1}\right)$; by Ayalew and Selassie [5] for the Guang watershed in the Northwestern Ethiopia (24.95 t $\mathrm{ha}^{-1}$ year $\left.^{-1}\right)$; by Gashaw et al. [22] for the Geleda Watershed in the Northwestern Ethiopia (23.7 $\mathrm{t} \mathrm{ha}^{-1}$ year $^{-1}$ ) and by Amsalu and Mengaw [3] for the JabiTehinan watershed in the Northwestern Highlands $\left(30.4 \mathrm{t} \mathrm{ha}^{-1}\right.$ year $\left.^{-1}\right)$. 


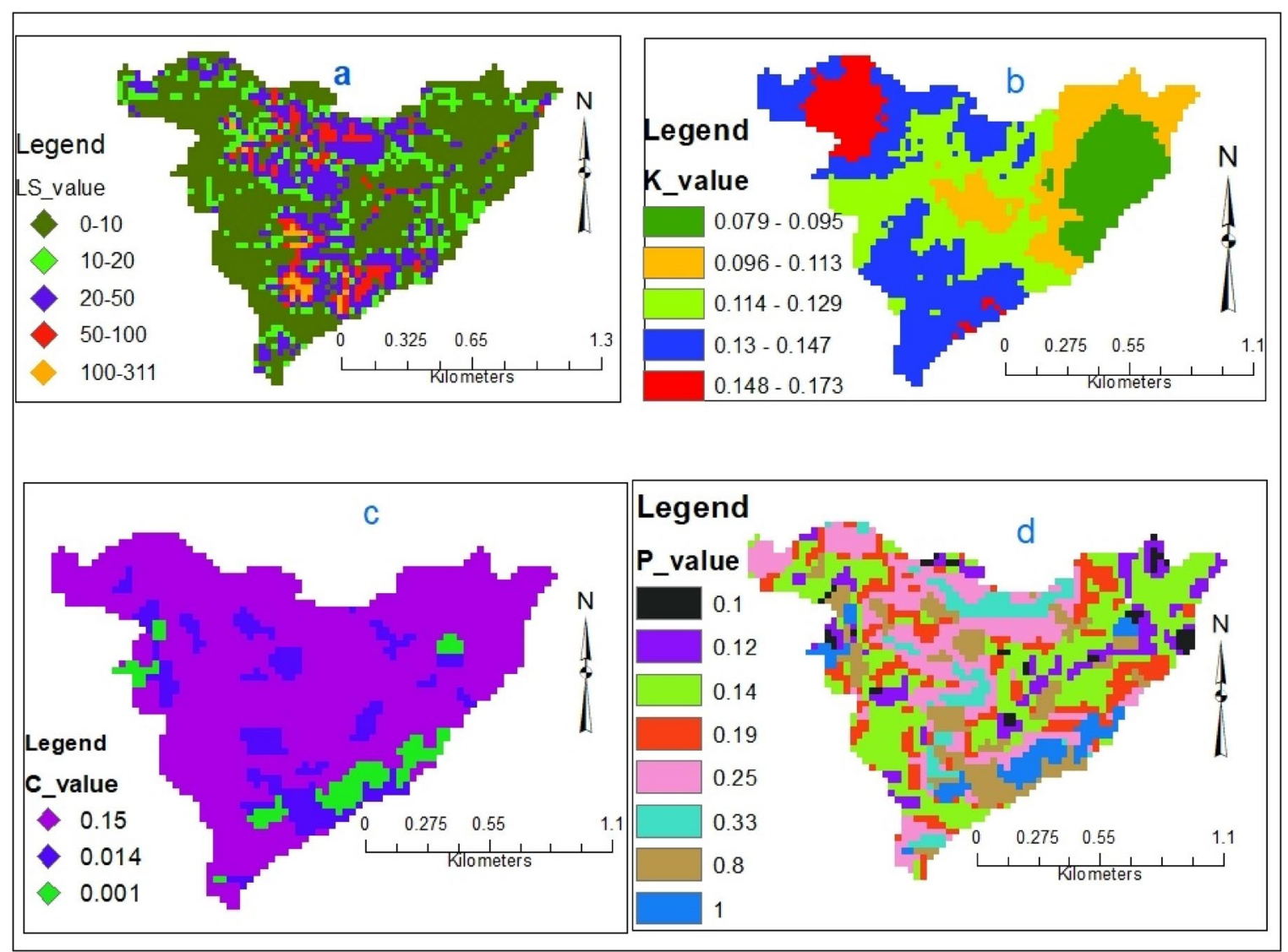

Fig. 7 a Slope length $(L)$ and steepness (S). b Soil erodibility $(K), \mathbf{c}$ cover and management $(C)$ factor and $\mathbf{d}$ conservation practice $(P)$ factor

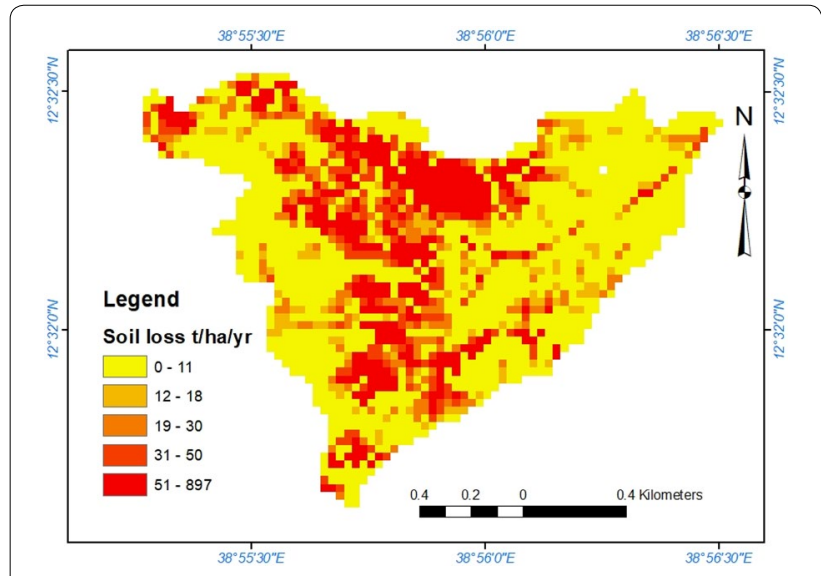

Fig. 8 The average annual soil loss of Agewmariam watershed

Unlike our findings, some studies, however, reported high erosion rate in different parts of Ethiopian highlands. For example, Bewket and Teferi [7] for the Chemoga watershed of the Blue Nile basin in the northwestern highlands of Ethiopia (93 tha $\mathrm{tear}^{-1}$ ) and Gelagay and
Minale [26] for the Koga watershed in Blue Nile basin $\left(47.4 \mathrm{t} \mathrm{ha}^{-1}\right.$ year $\left.^{-1}\right)$. The relatively low average soil erosion rate in our study could be due to topography with average slope (27\%) and the cultivated areas are located in the gentle slopes of the catchment.

On the other hand, other studies reported lower erosion rates than our study, for instance, Brhane and Mekonen [11] reported $9.63 \mathrm{t} \mathrm{ha}^{-1}$ year $^{-1}$; Gizachew [27], $9.1 \mathrm{t} \mathrm{ha}^{-1}$ year $^{-1}$; Gerawork and Awdenegest [24], $7.47 \mathrm{t} \mathrm{ha}^{-1}$ year $^{-1}$; Eshete [18], $4.17 \mathrm{t} \mathrm{ha}^{-1}$ year $^{-1}$ and Tiruneh and Ayalew [54], $4.81 \mathrm{t} \mathrm{ha}^{-1}$ year $^{-1}$ in the highlands of Ethiopia.

The variation in the results may be attributed to the varying soil factors in the different study areas and thus one cannot expect agreement while the biophysical factors of the various watersheds are not the same. In the study area, as expected, high erosion rate was recorded in the steeper slope area of the watershed (Fig. 7) that ranges from 30 to $83 \%$ and the steeper slope land use of agricultural lands. High erosion rate occurring on the steep slopes were reported in similar studies [11, 22] (Table 6). 
Table 6 Conservation practices factor $(P$-value) $[4,57]$

\begin{tabular}{lll}
\hline Land-use type & Slope class & $\boldsymbol{P}$ factor \\
\hline Agriculture land & $0-5$ & 0.1 \\
& $5-10$ & 0.12 \\
$10-20$ & 0.14 \\
& $20-30$ & 0.19 \\
& $30-50$ & 0.25 \\
& $>50$ & 0.33 \\
Shrubland & & 0.8 \\
Forest land & & 1 \\
\hline
\end{tabular}

Table 7 Average soil loss in land use land cover types

\begin{tabular}{lllll}
\hline No. & LULC & $\begin{array}{l}\text { Average soil loss t } \\
\text { ha }^{-\mathbf{1}} \text { year }^{-\mathbf{1}}\end{array}$ & Area in ha & Percent \\
\hline 1 & Forestland & 1.4 & 10.55 & 5.8 \\
2 & Shrub land & 23.5 & 23 & 12.52 \\
3 & Agricultural & 27.6 & 149.6 & 81.68 \\
& Total & & 183.15 & 100 \\
\hline
\end{tabular}

Table 8 Annual soil loss rate, severity class and priority areas in the Agewmaryiam watershed

\begin{tabular}{llllrl}
\hline No. & $\begin{array}{l}\text { Soil loss } \\
\text { (t ha } \\
\text { year }^{-1} \text { ) }\end{array}$ & $\begin{array}{l}\text { Severity } \\
\text { classes }\end{array}$ & $\begin{array}{l}\text { Priority } \\
\text { classes }\end{array}$ & Area (ha) & Percent \\
\hline 1 & $0-11$ & Slight & V & 123.04 & 67.18 \\
2 & $12-18$ & Moderate & IV & 9.95 & 5.43 \\
3 & $19-30$ & High & III & 10.58 & 5.78 \\
4 & $31-50$ & Very high & II & 5.95 & 3.25 \\
5 & $51-897$ & Severe & | & 33.63 & 18.36 \\
Total & & & & 183.15 & 100 \\
\hline
\end{tabular}

The average soil loss was also estimated for the different land use land covers and slope classes. The analysis showed that the soil loss was higher on cultivated land $\left(27.6 \mathrm{t} \mathrm{ha}^{-1}\right.$ year $\left.^{-1}\right)$ followed by shrubland $\left(23.5 \mathrm{t} \mathrm{ha}^{-1}\right.$ year $\left.^{-1}\right)$; whereas, soil loss was lowest in forestland (1.4 $\mathrm{t} \mathrm{ha}^{-1}$ year $^{-1}$ ) illustrated in Table 7 . The main reason for decreasing soil loss of the forest land areas is that it has a thick layer of old leaf residue on the surface that protects against soil erosion. The forest canopy also reduced the raindrop power and detachment of soil. The current result was also confirmed by Rizeei et al. [47].

The slope class less than $3 \%$ covers an area of $2.5 \%$ of the total area and the erosion rate is least in this slope $\left(5.8 \mathrm{t} \mathrm{ha}^{-1}\right.$ year $\left.^{-1}\right)$. The $3-8 \%$ slopes extend over an

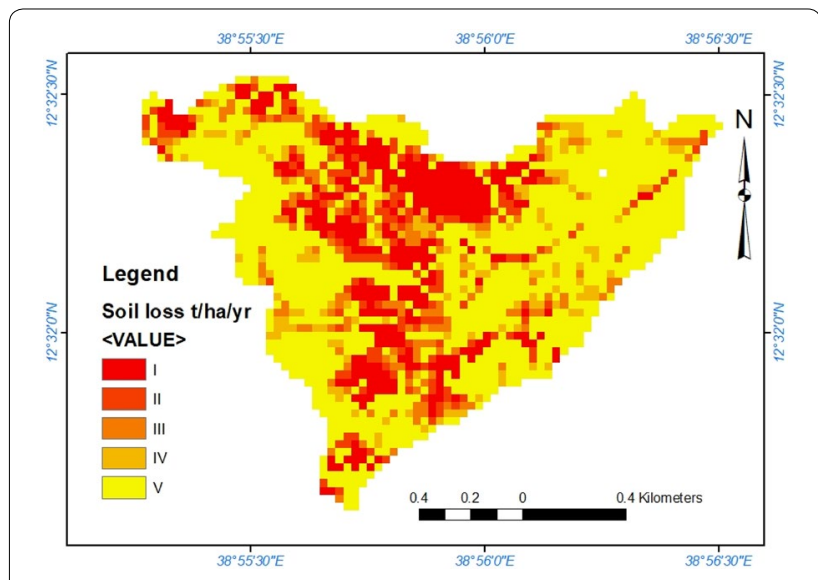

Fig. 9 Prioritization map for soil and water conservation planning

area of $10.5 \%$ of the total area (erosion rate is $9.9 \mathrm{t} \mathrm{ha}^{-1}$ year $^{-1}$ ). The slope class $8-15 \%$ covers $20.2 \%$ of the total area shows the erosion rate is $11.5 \mathrm{t} \mathrm{ha}^{-1}$ year $^{-1}$. The $15-30 \%$ slope occupies $30.4 \%$ of the area and the erosion rate is $22.3 \mathrm{t} \mathrm{ha}^{-1}$ year $^{-1}$. The $30-50 \%$ slope covers $22.1 \%$ of the area, which erosion rate is $35.69 \mathrm{t} \mathrm{ha}^{-1}$ year $^{-1}$. The greater than $50 \%$ slope covers the $14.3 \%$ of the area, where the erosion rate is $49.87 \mathrm{t} \mathrm{ha}^{-1}$ year $^{-1}$. Hence, more erosion was observed in high slope areas and sloppy cultivated land. Soil erosion is more and the top layer gets washed out and transported easily due to the steepness of the slopes. The current result also conformed with similar findings reported by Mondal et al. [38], Brhane and Mekonen [11], Gashaw et al. [22].

\section{The priority of management requirement}

Prioritization of intervention areas was based on the severity and risk of soil erosion imperative. Hence based on the estimated rates of erosion the study watershed is classified and ranked into five priority classes as shown in Table 8 and Fig. 8. Primary USLE was used for conservation planning by comparing the computed soil loss with the soil loss tolerance value of the study area. In the study area, the soil loss rate was compared with the soil loss tolerance value, i.e., $5-11 \mathrm{t} \mathrm{ha}^{-1}$ year $^{-1}$ as it was estimated for the highlands of Ethiopia by Renard et al. [46].

The results of soil loss analysis showed that about $66.5 \%$ of the watershed was categorized as low erosion risk rate which is below soil loss tolerance value range adapted to the highlands of Ethiopia [47]. The remaining 33.5\% of watershed was classified under moderate-to-severe risk classes which are above maximum tolerable soil loss (11 t $\mathrm{ha}^{-1}$ year $^{-1}$ ) (Table 8 and Fig. 9). It can be observed from the assigned class that the different priority areas contributed differently to the total erosion rate. For instance, priority class I covers $18.36 \%$ of the entire watershed, II and 
III cover combined $9.1 \%$ of the watershed. These priority classes highly contributed to soil loss [48].

\section{Conclusions}

This study used the USLE equation with GIS techniques to assess soil loss rate and identify the hotspot areas in Agewmairium watershed. The spatial distribution map of soil loss in the watershed was generated. The average soil loss varied from 0 to $897 \mathrm{t} \mathrm{ha}^{-1} \mathrm{year}^{-1}$. The mean soil loss from the entire watershed was $25 \mathrm{tha}^{-1}$ year $^{-1}$ which is above the tolerable limit. High soil erosion rate is attributed to high value of slope length and gradient of the watershed. Areas with high erosion rates require immediate action of soil conservation practices. The land management strategies to be implemented should match the characteristics of the topography, land use cover, and interest of the local community. Agroforestry, terracing, cut-and-carry system can be integrated to sustainably manage erosion-prone areas of steep mountains area.

\section{Abbreviations}

DEM: Digital Elevation Model; GIS: Geographical Information System; SRTM: Shuttle Radar Topography Mission; USGS: United States Geological Survey; USLE: Universal Soil Loss Equation.

\section{Acknowledgements}

We thank the Amhara Agricultural Research Institute for providing financial support. We are grateful to the staff of Sekota Dryland Agricultural Research Center for their frequent technical and logistical support and creating good working environment. We are very grateful to the anonymous reviewers for their constructive comments.

\section{Authors' contributions}

GGi: collected, analyzed, interpreted the data and wrote the paper. AMo and AMu: development of the methodology, supervision and review and editing the paper. All authors read and approved the final manuscript.

\section{Funding}

Amhara Agricultural Research Institute, Ethiopia.

\section{Availability of data and materials \\ Not applicable.}

Ethics approval and consent to participate

Not applicable.

\section{Consent for publication}

Not applicable.

\section{Competing interests}

The authors declare that they have no competing interests.

\section{Author details}

1 Soil and Water Management, Sekota Dryland Agricultural Research Center, Sekota, Ethiopia. ${ }^{2}$ Biosystems Engineering Department, Hawassa University, Hawassa, Ethiopia.

Received: 31 January 2020 Accepted: 14 July 2020

Published online: 30 September 2020

\section{References}

1. Alemayehu G, Alamirew T. Testing and Validation of the Revised Universal Soil Loss Equation (RUSLE-2) at the Twin Catchments of Gununo, Wolaita. PhD diss., Haramaya University, 2012.

2. Alexakis DD, Hadjimitsis DG, Agapiou A. Integrated use of remote sensing, GIS, and precipitation data for the assessment of soil erosion rate in the catchment area of "Yialias" in Cyprus. Atmos Res. 2013;1(131):108-24.

3. Amsalu T, Mengaw A. GIS-based soil loss estimation using rusle model: the case of jabi tehinan woreda, ANRS, Ethiopia. Nat Resour. 2014;19:2014.

4. Asmamaw LB, Mohammed AA. Identification of soil erosion hotspot areas for sustainable land management in the Gerado catchment, Northeastern Ethiopia. Rem Sens Appl. 2019;1(13):306-17.

5. Ayalew $G$, Selassie YG. Soil loss estimation for soil conservation planning using geographic information system in Guang watershed, Blue Nile basin. J Environ Earth Sci. 2015;5:126-34.

6. Bartoli F, Burtin G, Guerif J. Influence of organic matter on aggregation in Oxisols rich in gibbsite or in goethite II Clay dispersion, aggregate strength and water-stability. Geoderma. 1992;54(1-4):259-74.

7. Bewket W, Teferi E. Assessment of soil erosion hazard and prioritization for treatment at the watershed level: case study in the Chemoga watershed, Blue Nile basin, Ethiopia. Land Degrad Develop. 2009;20(6):609-22.

8. Birhanu A. Environmental degradation and management in Ethiopian highlands: review of lessons learned. Int J Environ Protect Policy. 2014;2(1):24-34.

9. BOA [Bureau of Agriculture]. Hag himra administration Zone. Sekota: Bureau of Agriculture; 2018.

10. Boorman DB, Hollis JM, Lilly A. Hydrology of soil types: a hydrologicallybased classification of the soils of United Kingdom. Roorkee: Institute of Hydrology; 1995.

11. Brhane G, Mekonen K. Estimating soil loss using Universal Soil Loss Equation (USLE) for soil conservation planning at Medego watershed, Northern Ethiopia. J Am Sci. 2009;5(1):58-69.

12. Dejene A. Integrated natural resources management to enhance food security. The case for community-based approaches in Ethiopia. Environment and Natural Resources. Working Paper (FAO). 2003.

13. Desta L. Land degradation and strategies for sustainable development in the Ethiopian highlands: Amhara Region. ILRI (aka ILCA and ILRAD); 2000.

14. Devatha CP, Deshpande V, Renukaprasad MS. Estimation of soil loss using USLE model for Kulhan Watershed, Chattisgarh-A case study. Aquatic Procedia. 2015;1(4):1429-36.

15. EMA [Ethiopia Mapping Authority]. National Atlas of Ethiopia. Addis Abeba: Ethiopia Mapping Authority; 2008.

16. EMS [Ethiopia Mapping Authority]. Meteorological Maps of Ethiopia. Addis Abeba: Ethiopian Meteorological Service; 2008.

17. El-Swaify SA, Dangler EW, Armstrong CL. Soil erosion by water in the tropics. Research extension series. Hawaii: University of Hawaii; 1992.

18. Eshete T. Spatial analysis of erosion and land degradation leading to environmental stress: the Case of Lake Hawassa Catchment. Doctoral dissertation, Addis Ababa University; 2009.

19. FAO/UNDP. The methodology used in the Development of Soil Loss Rate Map of the Ethiopian Highlands Field document 5. Addis Ababa: FAO/ UNDP. 1984.

20. Foster GR, McCool DK, Renard KG, Moldenhauer WC. Conversion of the universal soil loss equation to SI metric units. J Soil Water Conserv. 1981;36(6):355-9.

21. Gachene CK. Evaluation and mapping of soil erosion susceptibility: an example from Kenya. Soil Use Manag. 1995;11(1):1-4.

22. Gashaw T, Tulu T, Argaw M. Erosion risk assessment for prioritization of conservation measures in Geleda watershed, Blue Nile basin, Ethiopia. Environ Syst Res. 2018;6(1):1.

23. Gee GW, Bauder JW. Particle size analysis. Methods of soil analysis. Am Soc Agron. 1986;7:383-411.

24. Gerawork B, Awdenegest M. Erosion hazard assessment using remote sensing and GIS: the Case of Gibe-III Dam Catchment, Southwest Ethiopia. Doctoral dissertation, Haramaya University. 2014.

25. Gessesse B, Bewket W, Bräuning A. Model-based characterization of runoff and soil erosion in response to land use/land cover changes in the Modjo watershed, Ethiopia. Land Degrad Develop. 2014. https://doi. org/10.1002/ldr.2276. 
26. Gelagay HS, Minale AS. Soil loss estimation using GIS and Remote sensing techniques: a case of Koga watershed, Northwestern Ethiopia. Int Soil Water Conserv Res. 2016;4(2):126-36.

27. Gizachew A. Geographic information system based soil loss and sediment estimation in zingin watershed for conservation planning, highlands of Ethiopia. Int J Sci Technol Soc. 2015;3(1):28.

28. Hailu A, Klike A. Predicting the spatial distribution of soil erodibility factor using USLE nomograph in an agricultural watershed, Ethiopia. Int Soil Water Conserv Res. 2015;3:282-90.

29. Hardy EE, Anderson JR. A land-use classification system for use with remote sensor data. In: LARS Symposia. 1976. p. 2.

30. Hawando T. The survey of the soil and water resources of Ethiopia. UNU/ Toko; 1995.

31. Helldén U. An assessment of woody biomass, community forests, land use and soil erosion in Ethiopia. A feasibility study on the use of remote sensing and GIS [geographical information system]-analysis for planning purposes in developing countries. Lund: Lund University Press; 1987.

32. Hurni $H$, Solomon A, Amare B, Berhanu D, Ludi E, Portner B, Birru Y, Gete Z Land degradation and sustainable land management in the Highlands of Ethiopia In: Hurni H, Wiesmann U, editors. Global change and sustainable development: a synthesis of regional experiences from research partnerships. Perspectives of the Swiss National Centre of Competence in Research (NCCR) North-South, University of Bern, Vol. 5. Bern: Geographica Bernensia; 2010. pp 187-207.

33. Hurni H. Erosion-productivity-conservation systems in Ethiopia. 1985. pp 654-74.

34. Kassie M, Pender J, Yesuf M, Kohlin G, Bluffstone R, Mulugeta E. Impact of soil conservation on crop production in the Northern Ethiopian Highlands. IFPRI Discussion Paper 00733. Washington D.C., USA: International Food Policy Research Institute; 2007.

35. Lanckriet S, Derudder B, Naudts J, Araya T, Cornelis W, Bauer H, Deckers J, Haile M, Nyssen J. Politics of land degradation under different land policies in the North Ethiopian Highlands. Land Degrad Develop. 2014. https ://doi.org/10.1002/ldr.2278.

36. Meshesha DT, Tsunekawa A, Tsubo M, Haregeweyn N. Dynamics and hotspots of soil erosion and management scenarios of the Central Rift Valley of Ethiopia. Int J Sedim Res. 2012;27(1):84-99.

37. Molla T, Sisheber B. Estimating soil erosion risk and evaluating erosion control measures for soil conservation planning at Koga watershed in the highlands of Ethiopia. Solid Earth. 2017;8(1):13.

38. Mondal A, Khare D, Kundu S. Impact assessment of climate change on future soil erosion and SOC loss. Nat Hazards. 2016:82(3):1515-39.

39. Moore ID, Burch GJ. Modelling erosion and deposition: topographic effects. Trans ASAE. 1986;29(6):1624-30.

40. Morgan RP. Soil erosion and conservation. New York: Wiley; 2005.

41. Muche $H$, Temesgen M, Yimer F. Soil loss prediction using USLE and MUSLE under conservation tillage integrated with 'fanya juus' in Choke Mountain, Ethiopia. Int J Agric Sci. 2013;3(10):046-52.

42. Nelson DW, Sommers L. Total carbon, organic carbon, and organic matter 1. Methods of soil analysis Part 2. Chem Microbiol Prop. 1982;2:539-79.

43. Nigussie G, Fekadu M, Demissew S, Warkineh B. Impact of conservation management on land change: a case study in Guassa Community
Conservation Area for the last 31 years (1986-2015). Model Earth Syst Environ. 2019;5(4):1495-504.

44. Panagos P, Borrelli P, Meusburger K, Alewell C, Lugato E, Montanarella L. Estimating the soil erosion cover-management factor at the European scale. Land Use Policy. 2015;1(48):38-50.

45. Pimentel D, Kounang N. Ecology of soil erosion in ecosystems. Ecosystems. 1998;1(5):416-26.

46. Renard KG, Foster GR, Weesies GA, McCool DK, Yoder DC. Predicting soil erosion by water: a guide to Conservation Planning with the Revised Universal Soil Loss Equation (RUSLE). In: Agricultural Handbook. U.S. Department of Agriculture. 1996.

47. Rizeei HM, Saharkhiz MA, Pradhan B, Ahmad N. Soil erosion prediction based on land cover dynamics at the Semenyih watershed in Malaysia using LTM and USLE models. Geocarto Int. 2016;31(10):1158-77.

48. Shiferaw A. Estimating soil loss rates for soil conservation planning in the Borena Woreda of South Wollo Highlands, Ethiopia. J Sustain Develop Africa. 2011;13(3):87-106.

49. Tamene L, Vlek PL. Assessing the potential of changing land use for reducing soil erosion and sediment yield of catchments: a case study in the highlands of northern Ethiopia. Soil Use Manag. 2007;23(1):82-91.

50. Tadesse T, Haque I, Aduayi EA. Soil, plant, water, fertilizer, animal manure, and compost analysis manual. Addis-Ababa, Ethiopia: International Livestock Center for Africa; 1991.

51. Tesfaye A, Negatu W, Brouwer R, Van der Zaag P. Understanding soil conservation decision of farmers in the Gedeb watershed, Ethiopia. Land Degrad Develop. 2014;25(1):71-9.

52. Tiffen M, Mortimore M, Gichuki F. More people, less erosion: environmental recovery in Kenya. New York: Wiley; 1994.

53. Tilahun A, Teferie B. Accuracy assessment of land use land cover classification using Google Earth. Am J Environ Protect. 2015;4(4):193-8.

54. Tiruneh $\mathrm{G}$, Ayalew M. Soil loss estimation using geographic information system in enfraz watershed for soil conservation planning in highlands of Ethiopia. Int J Agric Res Innovat Technol. 2015;5(2):21-30.

55. Vaezi AR, Sadeghi SH, Bahrami HA, Mahdian MH. Modeling the USLE K-factor for calcareous soils in northwestern Iran. Geomorphology. 2007;97(3-4):414-23.

56. Vinay M, Mahalingam B. Quantification of soil erosion by water using gis and remote sensing techniques: a Study of Pandavapura Taluk, Mandya District, Karnataka, India. ARPN J. ARPN J Earth Sci. 2015;4(2):103-10.

57. Wischmeier $\mathrm{WH}$, Smith DD. Predicting rainfall erosion losses: a guide to conservation planning. New York: Department of Agriculture, Science, and Education Administration; 1978.

58. Wolka K, Tadesse H, Garedew E, Yimer F. Soil erosion risk assessment in the Chaleleka wetland watershed, Central Rift Valley of Ethiopia. Environ Syst Res. 2015;4(1):1-2.

59. Yonas R, Gebrehana G. Characterization of biophysical and socioeconomic aspects of Agewmariam Watershed. Unpublished paper; 2018.

\section{Publisher's Note}

Springer Nature remains neutral with regard to jurisdictional claims in published maps and institutional affiliations.

\footnotetext{
Ready to submit your research? Choose BMC and benefit from:

- fast, convenient online submission

- thorough peer review by experienced researchers in your field

- rapid publication on acceptance

- support for research data, including large and complex data types

- gold Open Access which fosters wider collaboration and increased citations

- maximum visibility for your research: over 100M website views per year
}

At BMC, research is always in progress.

Learn more biomedcentral.com/submissions 